\title{
Perceptions of Professional Ethics, in Young University Students of the Social Sciences
}

\author{
PhD Flor Ivett Reyes Guillén ${ }^{1 *}$, Socorro Fonseca Córdoba ${ }^{1}$, Leticia del Carmen Flores Alfaro ${ }^{1}$, \\ Delina Margarita Nañez Córdova ${ }^{1}$, Luis Enrique Nájera Ortiz ${ }^{2}$, Werclain Alejandro Gómez \\ Flores ${ }^{1}$, Raúl Vázquez Gutiérrez ${ }^{1}$ \\ ${ }^{I}$ Autonomous University of Chiapas, Mexico \\ ${ }^{2}$ College of Bachelors of Chiapas, Mexico
}

*Corresponding Author: PhD Flor Ivett Reyes Guillén, Autonomous University of Chiapas, Mexico

\begin{abstract}
This article details the results of an investigation into the perceptions of young university students regarding professional ethics. It was held in a university faculty of Chiapas, Mexico, where professionals are formed in the social sciences. Among the most important findings are those related to the identification that students have with the chosen profession, unfortunately is high the percentage that is not identified with it or motivated by their professional training, Elements that directly influence the perception of professional ethical performance.
\end{abstract}

Keywords: Professional Ethics, Perceptions, Youth, University, Chiapas Mexico

\section{INTRODUCTION}

This paper presents the results of a study on the perceptions of professional ethics in young university students. Perceptions are related to variables such as values-based training, self-assessment, and the environment, an existing relationship between value education and the process of vocational training. Now, we can ask, is it the task of the university to form values? how can the university measure the training and development of professional values?

Education in values does not correspond only to basic educational levels, but also to the field of higher education (Abundis de León, 2011; Cortina, 2013). In this project, it is intended to identify and analyses the perceptions of young university students regarding professional ethics, identifying the degree to which the university is currently concerned about the teaching of professional ethics and in this sense the Students ' perception of this educational need at the university level.

For the design and analysis of this research, it is understood by professional ethics the correct performance of the own professional activity within the social context in which the person is unfolding (Escobar, 1989; Echeverría, 2013). It is in the professional practice where man finds the means with which to contribute to raise the degree of humanization of the private and social life (Batallosa, 1998; Rodríguez et al, 2015). With respect to the ethics of the university student, this is based on values and principles that compromise it in front of the university; But also, the community or society in general.

In this sense, ethics form free People, responsible for a being and being with oneself and with its surroundings. The individual is a sociable being, coexisting in society, is not born with an ethical code, identifies his personality and from being recognized gives meaning to his own life.

The ethics of the university student should not be limited to generating an egocentric thinking and acting ("study to be someone in life", p. example) but rather must be a way of life. Therefore, the University of the 21 st century, should be to stop being a space only to transmit knowledge disciplinary to locate in the center to the student with the awareness of the preservation of the species, the coexistence, the promotion of values, the Altruism and above all the desire to humanize the professional development of the university students.

Because, ethics form free subjects, able to make decisions in a free and responsible way, it becomes crucial within the training of the professional, having the values and ethical training for the further development of his profession, under social commitment and Self-respect 
The foregoing makes it clear that the individual transforms reality and in doing so transforms itself. In other words, if you act positively, you build; But if you act in a negative way, you destroy it. Therefore, ethics have its foundation in the fact that the subject is not born, it must be done, forge his personality and give meaning to his life.

As UNESCO (1989) has been mentioning for three decades, in university education it cannot focus exclusively on academia, but also on the human, integral and ethical formation of the individual for their interaction Professional with the society in which it unfolds. This has been retaken and worked by new competency-based educational models; But the ethical level is not yet achieved within the training plans.

Because of this and knowing that, at present, some students and even teachers, do not repair in the collective benefit nor in the ethical forms of relationship with the society; This project aims to identify and analyses the perceptions of professional ethics in young university students as part of their theoretical and methodological formation within the social sciences area.

\section{RESEARCH METHOD}

The present study shows a scheme of methodological phases with different temporal location:

First phase. Identification of perceptions of professional ethics. The study, cross-curricular, was held in the Faculty of Social Sciences of the Autonomous University of Chiapas, located in the city of San Cristóbal de Las Casas, Chiapas, Mexico in the year 2018.

Inclusion criteria: Students enrolled in the educational institutions selected for the study and who agreed to participate in the study.

Exclusion criteria: Students enrolled in the educational institutions selected for the study who did not agree to participate.

Application of a survey for perceptions on professional ethics. The sampling was randomized by $18 \%$ $(n=100)$ of the total number of students enrolled in the Faculty of Social Sciences, UNACH during the period August-December $2018(\mathrm{n}=544)$. Sampling was carried out on an equal basis of proportions by gender.

Second phase: Data analysis. A descriptive statistical analysis was carried out for the variables measured in the survey, as well as the variables observed by the investigator. This also made comparison calculations between variables by gender. The statistical program SPSS V18 was used.

\section{RESULTS AND ANALYSIS OF INVESTIGATIONS}

The results found in the study whose sample was $n=100$, of which $6 \%$ correspond to students of the degree in Social Anthropology, 14\% degree in history, 18\% degree in sociology and 62\% degree in Economy. The sample was obtained with 50\% male gender and 50\% female gender, none mentioned a gender other than these.

The average age of the youth interviewed is 25 years (Min 18-Max 29). Regarding the religion they profess, 56\% Catholics, 30\% do not have a religion, $8 \%$ Presbyterian and 6\% Christian.

As for the place of origin, 36\% are originating in San Cristóbal de Las Casas, 12\% Huixtán, 6\% Ocosingo and $6 \%$ Tapachula, the remaining $40 \%$ is divided between various municipalities in the state of Chiapas.

\section{VARIABLes OF IDENTIFICATION OF PERCEPTIONS:}

With respect to the valuation of the professional knowledge, the $76 \%$ of young interviewed mentions that they value the profession that they chose, the remaining percentage are undecided about it; but only $68 \%$ identify with the profession they chose and feel satisfied. Of this $68 \%$ as a universe, $75 \%$ study the degree in economics.

Specifically, on the updating and practice of interdisciplinarity, only $42 \%$ consider this practice necessary, but if they are willing to pay for continuing education (courses, diplomas, postgraduate degrees).

$65 \%$ of those interviewed, consider empathy, communication and trust as elementals for the good treatment and service to the client or user of their profession. The remaining percentages do not consider it basic or are undecided in its effectiveness in relation to the user. 
$54 \%$ of respondents consider that the values are contained in the educational programs to which they were inserted; While the remaining percentage (46\%) They don't identify him that way.

In professional practice confidentiality and doing the right thing professionally make you be at peace with yourself, is what you consider $73 \%$ of the young people interviewed in the study. This same percentage $(73 \%)$ He says that during the professional period it helps a lot to have a positive attitude to adversity and to overcome challenges.

In specific, $72 \%$ believe that ethical training may be necessary to confront labor disputes and be able to make good decisions by counting on oneself.

However, the previous figures, only 52\% enjoy learning something new. Also, $64 \%$ say that you do not need to know or practice the values of your profession in order to exercise it and what interests you preferably are to earn money and prestige.

When talking about human behavior, we talk about so many perceptions, attitudes and practices as individuals, so it becomes complex to recognize the different attitudes that will be formed in the human mind in different situations. It is therefore not easy or possible to make simple, concrete and clear generalizations about what people perceive, their attitudes and what they practice. Therefore, in the present study we rely on the claims of Amoros (2007) regarding human behavior in organizations and mentions that for their understanding we go from the individual level to the group and the systems.

However, within the university training, it is considered the work for a comprehensive training, which includes training in relation to capacities, competencies and values. Therefore, the attitudes that form the personality of the University student contribute to the socially responsible professional performance.

In this way, the results of the research have clearly thrown the importance of ethical training as part of the professional dimensions that articulated prepare the practitioner of the 21 st century, a completely globalized century and today with important political, economic and cultural transformations.

No doubt we are currently facing a complex world, involved in individualism and the indiscriminate search of material goods, so that the state also has a great role and commitment to give citizenship all those conditions Insurers of a better quality of life and a comprehensive training that includes a high level of citizenship.

In the study, young people mostly value the chosen profession (76\%) Feeling satisfied with it (68\%); But unfortunately the percentage that does not value their choice $(24 \%)$ is high, this percentage is at risk of not articulating the responsibility, dedication and ethics for a correct social commitment during its Professional practice; Or, opt for desertion before completing your studies.

While it is true that, in countries like Mexico, poverty and inequality play a prominent role in the list of dropout factors, it is also true that in studies carried out by Casillas and collaborators (2007) and De Garay (2004), it is clear that the factors of Cultural elements, organizational climate, affinity with the profession of choice and the linkage between institution and students are latent causes of university dropout.

Talking about continuing education for professionals is to speak of an indispensable need to ensure the quality and relevance of the services provided by the professional and increase their responsiveness. Even more so if we are in a century where globalization generates specific demands. Within the needs that a professional should cover through continuing education are (URS, 2015):1) New conceptions, paradigms and philosophies; 2) needs and demands; 3) technological development; 4) Training gaps; 5) Professional roles.

In the present study, it is very low the percentage that they have this interest on the continuous training. Less than half of those interviewed consider it necessary to update and interdisciplinary practice (42\%), however, this percentage if they agree to invest economically in their training.

However, about the elements related to the values and sensitivities inserted in the chosen profession, $65 \%$ of the students interviewed mention that empathy, communication and trust are elementary for the good treatment and customer service or User of his profession. Unfortunately, we are facing a $35 \%$ that do not consider it that way. It is important to mention that a similar percentage (46\%) It is the one that does not visualize the teaching of the importance of the values within the curriculum to which they are inserted. 
Despite the foregoing, more than $70 \%$ believe that confidentiality, positive attitude and ethical training are fundamental elements for decision-making, face challenges and security in themselves, 64\% think that it is not necessary to know and practice the values of their Profession to exercise it and are limited to having an interest in earning money and prestige as professionals.

This reality demonstrates the ethical need for professional behaviour, from its university formation, based on commitment, respect, responsibility, teamwork and integrity. And as Ibarra (2005) mentions, everything related to professional and ethical responsibility are actions that affect social welfare, a society that needs to retake the values that generate environments of respect and peace.

\section{CONCLUSiOnS}

- As a conclusion, we can list the following statements:

- Professional ethics as a major element in university education, not only regulates behavior through defined criteria and values, but is also considered a fundamental axis for the success of the professional in his scientific, innovative and Social and human commitment.

- Professional ethics must now be considered a transversal element in all areas and disciplines in training.

- In order to recognize the ethical aspects in the formation of the university student, the results of the present study reflect the principle of responsibility, competences and professional capacities.

- Professional and social responsibility because the profession's service is aimed at a demanding society and its knowledge favors the resolution of problems and contribution of resolvent measures.

- Recognition of capacities and competencies because they are fundamental within the structure of the civic competencies that strengthen our social environment.

- Finally, it is important to remember that in the work of the university teacher is to recognize the student as an individual with the need to develop their professional training process within the following areas:

$>$ Integrity. Based on the training of an honest and fulfilled professional in terms of its functions.

$>$ Commitment. With a positive attitude in their professional performance making sure of it from their optimistic performance as a college student.

$>$ Compliance. Based on a behavior of respect, to interaction and assertive relationships both in his position as a student and in the professional position his exit.

The present study then reveals the need for interdisciplinary work from the basic level to improve the choice of university studies in relation not only to their capacities and competencies, but also according to the motivation and affinity with Nature of the profession to choose.

\section{REFERENCES}

[1] Abundis de León, F (2011). Universidad y formación de valores en un contexto postmoderno. file:///C:/ Users/Ivett\%20Reyes/Downloads/Dialnet-UniversidadYFormacionDeValoresEnUnContextoPosmoder4034807.pdf

[2] Cortina, A. (2013) ¿Para qué sirve realmente la ética? Barcelona, Paidós.

[3] Escobar, J (1989). Ética. México. Editorial Mc Graw Hill.

[4] Echeverría, F. C. (2013). Educación ética: ¿Normas o virtudes? ¿Qué giro debe de tomar la enseñanza de la ética en la formación de universitarios solidarios? Persona bioética, 17(2) 151-167. Doi: 10.5294/ pebi. 2013.17.2.1

[5] Batallosa Navas, Juan M., (1998), “Más allá de la L.O.G.S.E: Una reflexión sobre Ética y Educación”, en www.nuevaalejandría.com/oo/colab/logse.htm

[6] Rodríguez, D., Ramírez, M., y Ramírez, P. (2015). Formación profesional: Integrando saberes éticos y de Desarrollo sostenible. Caso práctico para ingeniería. Sinéctica Revista electrónica de Investigación, 45. Recuperado de ile:///C:/Users/revista\%20Rexe/Downloads/2015-Ingenieria-rev\%20Sinectica\%20 (Ramir ez-Ramirez).pdf 
[7] UNESCO (1989). La contribución de la educación superior al sistema educativo en su conjunto. Conferencia Mundial sobre Educación Superior. Australia.

[8] Amorós, E (2007). Comportamiento organizacional. En busca del desarrollo de ventajas competitivas. Escuela de Economía. Universidad Católica Santo Toribio de Mogrovejo - USAT (Perú).

[9] Casillas, M., R. Chaín y N. Jácome. (2007). "Origen social de los estudiantes y trayectorias estudiantiles en la Universidad Veracruzana”, Revista de la Educación Superior, Vol. xxxvi, núm. 142.

[10] De Garay, A. (2004). Integración de los jóvenes en el sistema universitario, Barcelona, Editorial Pomares.

[11] URS, Universidad Regional del Sureste. (2015). Programa de Educación Continua. Consultado el 17/02/2019 en: http://www.urse.edu.mx/wp-content/uploads/2016/11/PROGRAMA-DE-EDUCACIONCONTINUA.pdf

[12] Ibarra,RG. (2005). Ética y formación profesional integral. Reencuentro. Análisis de problemas universitarios. Fecha de Consulta: 10 de febrero 2019. Disponible en: http://www.redalyc.org/ articulo.oa?id=34004303 ISSN 0188

\section{AUTHORS' BIOGRAPHY}

Ivett Reyes Guillén, $\mathrm{PhD}$ in Sciences, Natural Resources and Sustainable Development from El Colegio de la Frontera Sur. Professor-Researcher of the Faculty of Social Sciences of the Autonomous University of Chiapas, Mexico. President of the Research Network in Public Health and Care for Development Problems, REINVESAD. Member of the academic corps, society, culture and education Research line: Cognitive analysis for the interpretation of social processes and development. Society, Sustainability and Health. Calle presidenteobregón s/n Fracc. Revolución Mexicana C.P. 29210.

Socorro Fonseca Córdoba, PhD in education from the Institute of University Studies. ProfessorResearcher at the Faculty of Social Sciences, Campus III, UNACH. Member of the academic corps, society, culture and education. Calle presidenteobregón s/n Fracc. Revolución Mexicana C.P. 29210

Leticia del Carmen Flores Alfaro, $\mathrm{PhD}$ in public health Sciences by the Institute of Sciences and Arts of Chiapas. Professor-Researcher at the Faculty of Medicine of the UNACH. Member of the Academic Corps Society, culture and education. Belisario Domínguez Kilómetro 1081, Colina Universitaria, 29050 Tuxtla Gutiérrez, Chis.01 9616153533.

Delina Margarita Nañez Córdova, PhD in Public Law from the University of the South. ProfessorResearcher at the Faculty of Law C-III of the UNACH. Centro Historico. C.P. 29220

Luis Enrique Nájera Ortiz, PhD in social and humanistic sciences. Professor of College of Bachelors of Chiapas. LGAC: Educational policies, public policies for adolescent population and educational orientation and mentoring. Facilitator of courses-workshops related to human development and accompaniment in didactic strategies. COBACH 58 PeriféricoNte.

Werclain Alejandro Gómez Flores, PhD in Public Law from the University of the South. ProfessorResearcher at the Faculty of Law C-III of the UNACH. Centro Historico

Raúl Vázquez Gutiérrez, Master's in psychology Professor-researcher of the Faculty of Law of the Campus III, UNACH. Research line: Human Rights and Sexuality. Centro Historico. C.P. 29220

Citation: PhD Flor Ivett Reyes Guillén, et.al. "Perceptions of Professional Ethics, in Young University Students of the Social Sciences" International Journal of Research in Sociology and Anthropology (IJRSA), vol 5, no. 1, 2019, pp. 28-32. doi:http://dx.doi.org/ 10.20431/2454-8677.0501004.

Copyright: (C) 2019 Authors. This is an open-access article distributed under the terms of the Creative Commons Attribution License, which permits unrestricted use, distribution, and reproduction in any medium, provided the original author and source are credited. 